\title{
Charcot-Marie-Tooth families in Japan with MPZ Thr 124Met mutation
}

\author{
S Kurihara, Y Adachi, C Imai, H Araki, N Hattori, C Numakura, Y Lin, K Hayasaka, G Sobue, \\ K Nakashima
}

J Neurol Neurosurg Psychiatry 2004;75:1492-1494. doi: 10.1136/jnnp.2003.020107

Background: The MPZ Thr 124Met mutation is characterised by a late onset, pupillary abnormality, deafness, normal or moderate decreased motor nerve conduction velocity, and axonal damage in sural nerve biopsy.

Objective: To investigate the clinical manifestations of the axonal or demyelinating forms of the Japanese MPZ Thr124Met mutation originating in four different areas: Tottori, Nara, Aichi, and Ibaragi.

Results: Genotyping with DNA microsatellite markers linked to the MPZ gene on chromosome 1q22-q23 showed shared allelic characteristics between $12.65 \mathrm{cM}$ and revealed a common haplotype in all Tottori families. Aichi and Ibaragi families shared parts of the haplotype around the MPZ gene. However, there was no consistency with a Nara family. Conclusions: The high frequency of this peculiar genotype in the Tottori CMT population is presumably due to a founder effect, but in Thr124 it might constitute a mutation hotspot in the MPZ gene.

\footnotetext{
A
} bout one in 2500 persons have a form of CharcotMarie-Tooth disease (CMT), making it the most common inherited neuromuscular disorder. ${ }^{1}$ CMT falls into two large subtypes-the demyelinating form, CMTl, and the axonal form, CMT2. ${ }^{2}$ CMT1B can be caused by mutations in peripheral myelin protein zero (MPZ or P0), especially mutations located in the extracellular domain of the protein. ${ }^{3}$ Interestingly, CMT2 patients carry distinct point mutations in the MPZ gene initially thought to be exclusively involved in the pathogenesis of demyelinating hereditary neuropathies. ${ }^{4-9}$ The MPZ Thr 124Met mutation is included this group. ${ }^{10}{ }^{11}$ The mutation is associated with a clinically distinct phenotype characterised by late onset, marked sensory abnormalities, and in some families deafness and pupillary abnormalities. Sendrek et al, investigating a general European population, considered that Thrl24Met might constitute a mutation hotspot in the MPZ gene. ${ }^{12}$ In the present study, we clarified the clinical features of Japanese CMT families with the MPZ Thrl24Met mutation and the haplotype analysis of these Japanese ancestries. ${ }^{13}$

\section{METHODS}

Sixteen patients from Tottori, Nara, Aichi, and Ibaragi prefectures were examined by direct sequence analysis, which revealed a $\mathrm{C} \rightarrow \mathrm{T}$ mutation at position 371 in the MPZ gene, resulting in a substitution of methionine for threonine (Thrl24Met). After identifying the mutation, the clinical symptoms were studied.

Electrophysiological and pathological studies were done using standard protocols. To diagnose CMT2, we used the criteria of European CMT consortium, 1997. ${ }^{14}$ Amplification of repeat-containing regions was undertaken by polymerase chain reaction (PCR) for amplifying the microsatellite markers DiS2771, D1S2705, D1S2675, D1S1677, and DiS1595. These primers were as published by the Genome Database (http://Www.gdb.org), and sense primers were labelled with Cy5 fluorophores (SIGMA genosis, The Woodlands, Texas, USA). In order to determine accurate repeats numbers, PCR amplification was done and an aliquot of the product electrophoresed on a denaturing 6\% polyacrylamide gel with an automated DNA sequencer (ALF Express, Pharmacia LKB, Uppsala, Sweden). The data were processed using fragment analysis software (Fragment Manager, Pharmacia).

\section{RESULTS}

\section{Clinical features}

The clinical features of 16 patients are shown in table 1 . The mean (SD) age of symptom onset was at 51.1 (13.4) years. A pupillary abnormality was found in 14 patients and deafness in 11 , all with sensory deafness. Pes cavus is a frequent sign of CMT, but from this study we found that pes planus was also present in MPZ Thrl24Met patients. Neuropathic symptoms occurred later than usual for CMTl, and the patients were able to manage most aspects of their lives. Electrophysiologically, median motor nerve conduction velocities (MNCV) of MPZ Thrl24Met were normal (42.3 (15.6) $\mathrm{m} / \mathrm{s}$ ) and median nerve compound muscle action potentials (CMAP) were decreased (3.9 (3.9) mV). Sural nerve biopsies showed a marked decrease of large myelinated fibres and the presence of regenerating fibres with small onion bulb formation. Teased nerves mainly showed axonal degeneration.

\section{Haplotype analysis}

The haplotypes of the disease gene bearing chromosomes are shown in fig 1 . In 13 cases from the six Tottori originating CMT families there was a shared haplotype ("11-30-17-2113" repeats) for all five markers investigated (D1S1595, D1S2771, D1S2705, D1S2675, and D1S1677). Aichi and Ibaragi families shared parts of repeats between $2.57 \mathrm{cM}$ and $8.66 \mathrm{cM}$. However, the Nara originating family did not share contiguity markers (D1S2771, D1S2705).

\section{DISCUSSION}

Japanese CMT families with four isolated ancestries were studied. There are at least two founders and Thr124 was the hotspot in the MPZ gene. The disease usually manifested in about the fifth decade and showed slowly progressive

\footnotetext{
Abbreviations: CMAP, compound muscle action potential; CMT, Charcot-Marie-Tooth disease; CMT1, Charcot-Marie-Tooth disease type 1; CMT2, Charcot-Marie-Tooth disease type 2; DSS, DejerineSottas disease; MNCV, motor nerve conduction velocity; MPZ, myelin protein zero; NCV, nerve conduction velocity
} 
Table 1 Clinical, electrophysiological, and pathological data from Japanese MPZ Thr124Met patients

\begin{tabular}{|c|c|c|c|c|c|c|c|c|c|c|}
\hline $\begin{array}{l}\text { Patients, } \\
\text { family }\end{array}$ & $\begin{array}{l}\text { Age at onset } \\
\text { (years), sex }\end{array}$ & $\begin{array}{l}\text { Initial } \\
\text { symptom }\end{array}$ & $\begin{array}{l}\text { Gait } \\
\text { disturbance }\end{array}$ & $\begin{array}{l}\text { Pes cavus/ } \\
\text { pes planus }\end{array}$ & $\begin{array}{l}\text { Dys- } \\
\text { aesthesia }\end{array}$ & $\begin{array}{l}\text { Pupillary } \\
\text { abnormality }\end{array}$ & Deafness & $\begin{array}{l}\text { Median n } \\
\text { MNCV } \\
(\mathrm{m} / \mathrm{s})\end{array}$ & $\begin{array}{l}\text { Median } n \\
\text { CMAP } \\
(\mathrm{mV})\end{array}$ & $\begin{array}{l}\text { Sural nerve } \\
\text { pathology }\end{array}$ \\
\hline Tottori, A-1 & $57, M$ & Gait disturbance & + & C & + & + & + & 34.9 & 10.0 & OB, axonal loss \\
\hline A-2 & $70, F$ & Gait disturbance & + & $P$ & + & + & + & 50.5 & 4.0 & \\
\hline A-3 & $57, M$ & Dysaesthesia & - & C & + & - & - & & & \\
\hline Tottori, B-1 & $40, \mathrm{~F}$ & Dysaesthesia & + & C & + & + & + & ND & ND & $\begin{array}{l}\text { Decreased MF, } \\
O B(-)\end{array}$ \\
\hline B-2 & $40, \mathrm{~F}$ & Dysaesthesia & - & C & + & + & - & 51.2 & 10.1 & \\
\hline B-3 & $36, M$ & Dysaesthesia & + & $P$ & + & + & - & 47.5 & 2.5 & Decreased MF, \\
\hline B-4 & $20, M$ & $\begin{array}{l}\text { Dysaesthesia, } \\
\text { cramp }\end{array}$ & - & C & + & + & - & 47.1 & 11.1 & Myelin ovoid \\
\hline Tottori, C-1 & $60, M$ & Gait disturbance & + & $P$ & + & + & + & 35.8 & 2.0 & Decreased MF \\
\hline$C-2$ & $50, M$ & Gait disturbance & + & C & + & + & + & 45.4 & 0.66 & Small OB \\
\hline Tottori, D-1 & $50, M$ & Dysaesthesia & + & $P$ & + & + & + & 61.2 & 6.8 & \\
\hline D-2 & $60, \mathrm{~F}$ & Dysaesthesia & - & $P$ & + & - & + & 69.9 & & \\
\hline Tottori, E-1 & $44, \mathrm{~F}$ & Muscle weakness & + & C & + & + & + & 38.5 & 2.0 & $\begin{array}{l}\text { Decreased MF, } \\
O B(-)\end{array}$ \\
\hline Tottori, F-1 & $65, M$ & Gait disturbance & + & C & + & + & + & 38.8 & 0.25 & \\
\hline Nara & $50, \mathrm{~F}$ & Gait disturbance & + & C & + & + & + & 31.0 & 1.6 & $\begin{array}{l}\text { Decreased MF, } \\
O B(-)\end{array}$ \\
\hline Aichi & & Dysaesthesia & + & C & + & + & - & 40.0 & 2.3 & Sprouting, $\mathrm{OB}(-)$ \\
\hline Ibarag & 67 & Photophobia & + & C & + & + & + & 40.0 & 1.5 & Sprouting, $\mathrm{OB}(-)$ \\
\hline
\end{tabular}

Normal nerve conduction velocity values: motor median nerve, $>45-65 \mathrm{~m} / \mathrm{s}$. Normal amplitude values: motor median nerve, $>4-25 \mathrm{mV}$.

$C$, pes cavus; F, female; M, male; MF, myelinated fibres; MPZ, myelin protein zero; NCV, nerve conducting velocity; $N D$, not done; OB, onion bulb; $P$, pes planus.

neuropathic symptoms. Pupillary abnormalities and deafness are sometimes present in other inherited neuropathies, but they were a constant feature in this mutation. The NCVs varied widely from less than $38 \mathrm{~m} / \mathrm{s}$ to normal in early stage patients, and the values tended to fall within the range of CMTl in severely affected patients. Clusters of remyelinating axons in the sural nerve biopsy showed axonal involvement with axonal regeneration. ${ }^{11}$ Phenotype-genotype correlations in 16 patients indicated that these were difficult to classify as CMT1B or CMT2. This tendency might derive from the character of the MPZ Thr124Met mutation. ${ }^{10-12}{ }^{15}$ Haplotype analysis showed that the Nara CMT family was completely unrelated. However, other Japanese families shared a common founder. Thus more than two distinct ancestral Thr124 MPZ alleles exist in Japan. Our study strongly supports the hypothesis that the high frequency of the ACG to ATG transition in codon 124 is not only due to a founder effect, but that Thr124 is a mutation hotspot.

In conclusion, CMT patients with slightly reduced or nearly normal NCVs should be screened for MPZ mutations,

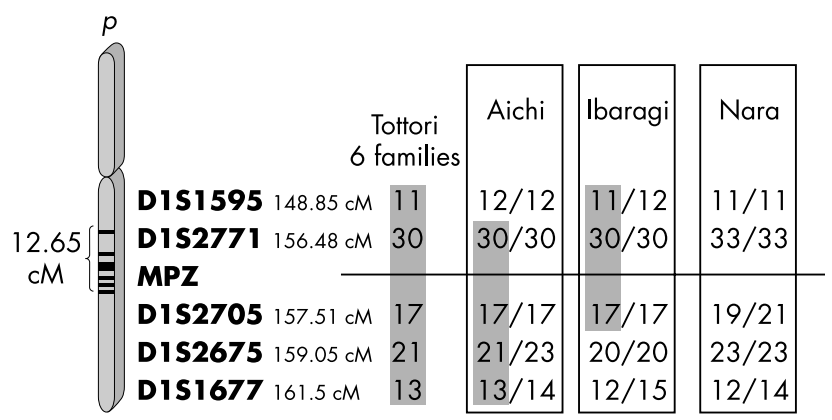

Chromosome 1

Figure 1 Disease associated haplotypes in Japanese Charcot-MarieTooth disease (CMT) families. In 13 cases from the six Tottori originating CMT families, there was a shared haplotype ("1 1-30-17-21-13" repeats) for all five markers investigated. Aichi and lbaragi families shared parts of repeats between $2.57 \mathrm{cM}$ and $8.66 \mathrm{cM}$. The Nara originated family did not share contiguity markers (D1S2771, DIS2705). particularly when additional clinical features such as pupillary abnormalities or deafness are also present.

\section{Authors' affiliations}

S Kurihara, Y Adachi, C Imai, H Araki, Department of Neurology, Institute of Neurological Sciences, Faculty of Medicine, Tottori University, Yonago, Japan

N Hattori, G Sobue, Department of Neurology, Nagoya University Graduate School of Medicine, Nagoya, Japan

C Numakura, K Hayasaka, Department of Paediatrics, Yamagata University, School of Medicine, Yamagata, Japan

Y Lin, Department of Immunology, National Institute of Neuroscience,

National Centre of Neurology and Psychiatry, Japan

Competing interests: none declared

Correspondence to: Dr Saiko Kurihara, Department of Neurology, Institute of Neurological Sciences, Faculty of Medicine, Tottori University, 36-1 Nishimachi, Yonago, Tottori 683-8504 Japan; psycho@

k3.dion.ne.jp

Received 3 June 2003

In revised form 25 December 2003

Accepted 13 January 2004

\section{REFERENCES}

1 Skre H. Genetic and clinical aspects of Charcot-Marie-Tooth's disease. Clin Genet 1974;6:98-118.

2 Dyck PJ, Chance P, Lebo R, et al. Hereditary motor and sensory neuropathies. In: Dyck PJ, Thomas PK, Griffin JW, et al, eds. Peripheral neuropathy. Philadelphia: WB Saunders, 1993:1094-136.

3 Kirschner DA, Inove H, Saavedra RA. Membrane adhesion in peripheral myelin: good and bad wraps with protein PO. Structure 1996;5:1239-44.

4 Marrosu MG, Vaccargiu S, Marrosu G, et al. Charcot-Marie-Tooth disease type 2 associated with mutation of the myelin protein zero gene. Neurology 1998; 50:1397-401.

5 Pareyson D, Sghirlanzoni A, Botti S, et al. Charcot-Marie-Tooth disease type 2 and PO gene mutations. Neurology 1999;52:1110-11.

6 Sendrek J, Hermanns B, Bergmann C, et al. X-linked dominant CharcotMarie-Tooth neuropathy: clinical, electrophysiological, and morphological phenotype in four families with different connexin 32 mutations. J Neurol Sci 1999; 167:90-101.

7 Silander K, Meretoja P, Pihko H, et al. Screening for connexin 32 mutations in Charcot-Marie-Tooth disease families with possible X-linked inheritance. Hum Genet 1997; 100:391-7.

8 Misu K, Yoshihara T, Shikama Y, et al. An axonal form of Charcot-MarieTooth disease showing distinctive features in association with mutations in the peripheral myelin protein zero gene (Thr124Met or Asp75Val). J Neurol Neurosurg Psychiatry 2000;69:806-11. 
9 Hanemann CO Gabreels-Festen AAWM, DeJongue P. Axon damage in CMT due to mutation in myelin protein PO. Neuromusc Disord 2001;11:753-6.

10 Chapon F, Latour P, Diraison P, et al. Axonal phenotype of Charcot-MarieTooth disease associated with a mutation in myelin protein zero gene. J Neurol Neurosurg Psychiatry 1999;66:779-82.

11 DeJonghe $\mathbf{P}$, Timmermen V, Ceuterick C, et al. The Thr124Met mutation in the peripheral myelin protein zero (MPZ) gene is associated with a clinically distinct Charcot-Marie-Tooth phenotype. Brain 1999;122:281-90.

12 Senderek J, Hermanns B, Lehmann U, et al. Charcot-Marie-Tooth neuropathy type 2 and PO point mutations: two novel amino acid substitutions (Asp61Gly; Try1 19Cys) and a possible "hotspot" on Thr 124Met. Brain Pathol $2000 ; 10: 235-48$
13 Kurihara S, Adachi Y, Wada K, et al. An epidemiological genetic study of Charcot-Marie-Tooth disease in western Japan. Neuroepidemiology 2002;21:246-50

14 Anonymous. 2nd Workshop of the European CMT Consortium: 53rd ENMC. International Workshop on Classification and Diagnostic Guidelines for Charcot-Marie-Tooth type 2 (CMT2-HMSN) and distal hereditary motor neuropathy (distal HMN-spinal CMT) 26-28 September 1997, Naarden, Netherlands. Neuromusc Disord 1998:8:426-431

15 Martini R, Zielasek J, Toyka KV, et al. Protein zero (PO)-deficient mice show myelin degeneration in peripheral nerves characteristic of inherited human neuropathies. Nat Genet 1995;11:281-6. 